\title{
BIOLOGY
}

\section{The effect of streptozotocin-induced diabetes on the copper content in the cells of the immune system of rats}

\author{
N. V. Hryhorova \\ Zaporizhzhya National University, Zaporizhzhya, Ukraine \\ Corresponding author. E-mail: nvgrigorova@ukr.net
}

Paper received 06.02.21; Accepted for publication 18.02.21.

\author{
https://doi.org/10.31174/SEND-NT2021-250IX31-01
}

\begin{abstract}
In rats with streptozotocin-induced diabetes in the thymic epithelial cells, blood lymphocytes and white pulp of the spleen, the copper content was determined by the cytochemical reaction of lumocupferon. It was found that increasing the severity of diabetes in animals was accompanied by the accumulation of intracellular metal. Injections of insulin, adrenaline, and prednisolone corrected excess copper in the studied cells of the immune system of rats with streptozotocin-induced diabetes. Such changes were more pronounced in the case of the combined action of adaptive hormones.
\end{abstract}

Keywords: immune system, copper, streptozotocin-induced diabetes.

Introduction. Today, diabetes mellitus (DM) is one of the most common diseases. Given that this pathology is accompanied by a large number of complications, namely, the development of organ-specific lesions of many organs and systems, the issues of prevention, early diagnosis and treatment of diabetes are of particular importance [1-3]. According to the World Health Organization, 175 million people with diabetes are registered in the world, and in 2025 there will be 340 million [4-6]. Over the last decade, the number of patients with diabetes in Ukraine has grown rapidly - from 1,8 to $2,8 \%$. However, studies show that their actual number is at least twice as high, as half of patients do not even know about their illness. Currently, 1,2 million people in Ukraine suffer from diabetes [7]. It is known that the cellular mechanisms of autoimmune aggression are the main cause of destruction of pancreatic $\beta$ cells in the course of insulindependent diabetes mellitus (IDDM). Lymphocytes and macrophages are involved in the autoimmune cell chain of immunity [8-10]. In recent years, it has become known that one of the main pathogenetic factors in the development of IDDM is a violation of the formation of central tolerance to pancreatic antigens, which may be caused by changes in the morphofunctional state of antigenpresenting cells of the thyroid gland [11]. But many questions remain unresolved. Therefore, studies of blood lymphocytes, white pulp of the spleen and thymus in IDDM are relevant.

A brief overview of publications on the topic. Of particular interest, in our opinion, are studies of the copper content in these cells, given the role of metal in strengthening the immune system. Copper has a pronounced immunomodulatory effect, which is clearly evident in the study of primary and secondary immune responses. Copper compounds are able to increase the proliferation of the slowly sedimentary fraction of thymocytes; violation of the immunological status by thymectomy or imuran leads to a negative balance. Copper alleviates the manifestations of autoimmune diseases (rheumatoid arthritis) [12-14]. The participation of copper in the body's protective reactions, in which the copper content in the blood increases [15-17]. The amount of this metal in lymphocytes and thymus was not determined due to the lack of cytochemical method of its detection. The development in our laboratory of the reaction of lumocupferon (LC) in the above cells allowed to conduct such studies. It was considered necessary to conduct comparative studies of the level of copper in blood lymphocytes, white pulp of the spleen and thymic epithelial cells (TEC) of diabetic animals.

Purpose of research. The aim of the study was to study the copper content in blood lymphocytes, white spleen pulp and TEC in different degrees of severity of streptozotocin-induced diabetes and in the conditions of action of adaptive hormones on the course of this disease in rats.

Materials and methods. The material of studies were blood smears, sections of white pulp of the spleen and thymus of 81 rats. In all experiments, intact animals served as controls $(n=16)$, because after studying the control group of animals (animals injected with saline) and the intact group (animals without intervention), data were obtained that did not differ statistically. Other rats were intraperitoneally administered streptozotocin at a dose of $200 \mathrm{mg} / \mathrm{kg}$. To compensate for the hypofunction of the insular apparatus, insulin was administered subcutaneously at a dose of 20 units of action $/ \mathrm{kg}$, diluted 2 times. The first injection was given 1 day after streptozotocin administration, the other injections were given daily for 4 days. Increased hypofunction of the insular apparatus was caused by the previous administration of adrenaline and prednisolone. Prednisolone was administered to animals intramuscularly, and adrenaline - subcutaneously in doses of $10 \mathrm{mg} / \mathrm{kg}$ and $0,05 \mathrm{mg} / \mathrm{kg}$, respectively. Two hours after the administration of adrenaline, prednisolone, insulin, and 5 days after the injection of the diabetogenic substance in animals for life, blood was taken from the tail to prepare smears. Pieces of thymus and spleen were taken from slaughtered animals to make sections. Studies using laboratory animals were conducted in accordance with the requirements of Article 26 of the Law of Ukraine "On protection of animals from cruel treatment", "European Convention for the protection of vertebrate animals" (Strasbourg, 1986) and the principles of bioethics.

Blood smears and frozen sections of the spleen and 
thymus 30-60 $\mu \mathrm{m}$ thick were fluorochromed for 1 hour with $0,1 \%$ aqueous solution of LC. Violet light filter (VLF-1) was used to excite luminescence, and yellow light filter (ELF-18) was used as a protective (ocular) filter. Under a fluorescent microscope, copper was detected by a yellow-green glow.

Evaluation of the intensity of staining of the cytoplasm of lymphocytes and TEK in setting the reaction of LC was performed using a microfluorimeter. The fluorescence intensity was expressed in conventional units (c.u.). The obtained results were statistically processed according to the Student's t-test using the program Statistica, 6.0.

Results and discussion. The obtained results indicate that in control (intact) rats the copper content was $75 \pm 5,8$ c.u. in blood lymphocytes, $58 \pm 4.2$ c.u. - in the lymphocytes of the spleen, $42 \pm 2,5$ c.u. - in TEC. In severe streptozotocin-induced diabetes in animals, an increase in copper levels in blood lymphocytes by $56 \%(117 \pm 13,3$ c.u.; $\mathrm{P}<0,01)$, lymphocytes of the white pulp of the spleen $-59 \%$ (92 $\pm 10,0$ c.u.; $\mathrm{P}<0,01)$, TEC $-79 \%$ (75 $\pm 8,3$ c.u.; $\mathrm{P}<0,001)$.

In moderate diabetes in rats, the metal content increased by $44 \%(108 \pm 8,3$ c.u.; $\mathrm{P}<0,01)$ in blood lymphocytes, $43 \%$ ( $83 \pm 7,5$ c.u.; $\mathrm{P}<0,01)-$ in lymphocytes of the white pulp of the spleen, $60 \%(67 \pm 5,8$ c.u.; $\mathrm{P}<0,01)-$ in the TEC.

In the case of the development of mild streptozotocininduced diabetes, the amount of copper in the cells of the blood, spleen and thymus of rats was higher than the control values, respectively, by $33 \% \quad(100 \pm 9,2$ c.u.; $\mathrm{P}<0,05), 29 \%(75 \pm 5.0$ c.u.; $\mathrm{P}<0,05)$ and $38 \%(58 \pm 5,0$ c.u.; $\mathrm{P}<0,01)$.

In animals that did not develop diabetes, the copper content increased in blood lymphocytes by $23 \%(92 \pm 4,2$ c.u.; $\mathrm{P}<0,05)$, lymphocytes in the white pulp of the spleen

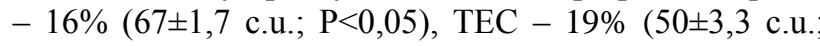
$\mathrm{P}<0,05)$.

The copper content increased on average by $44 \%$ (108 $\pm 7,5$ c.u.; $\mathrm{P}<0,01)$ in blood lymphocytes, $43 \%$ $(83 \pm 6,7$ c.u.; $\mathrm{P}<0,01)$ in lymphocytes white spleen pulp, $38 \%(58 \pm 4,2$ c.u.; $\mathrm{P}<0,01)-$ TEC of animals injected with streptozotocin.

Thus, in rats, the development of severe streptozotocininduced diabetes was accompanied by a significant accumulation of copper in blood lymphocytes, white spleen pulp and TEC. Less pronounced changes in the metal content in the studied cells were observed in moderate diabetes. An even smaller increase in intracellular copper was found in animals with a relatively mild form of the disease and, especially, in cases where diabetes did not develop.

A series of experiments was performed to determine the copper content in the cells of the immune system of rats with streptozotocin-induced diabetes under the action of adaptive hormones. After insulin injection in intact animals, the copper content decreased in blood lymphocytes by $33 \%(50 \pm 3,3$ c.u.; $\mathrm{P}<0,01)$, spleen lymphocytes -

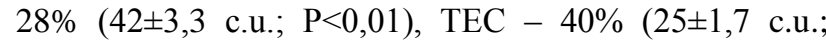
$\mathrm{P}<0,001)$. Adrenaline caused a decrease in metal content in blood lymphocytes by $44 \%$ ( $42 \pm 1,7$ c.u.; $\mathrm{P}<0,001)$, splenic lymphocytes - 43\% (33 $\pm 1,7$ c.u.; $\mathrm{P}<0,001)$, TEC - 40\% (25 $\pm 3,3$ c.u.; $\mathrm{P}<0,001)$. The decrease in copper content in the studied cells after injection of prednisolone was $33 \% \quad(50 \pm 3,3$ c.u.; $\mathrm{P}<0,001), 28 \% \quad(42 \pm 2,7$ c.u.; $\mathrm{P}<0,001)$, TEC $-21 \%$ ( $33 \pm 2,5$ c.u.; $\mathrm{P}<0,05)$.

After administration of insulin to rats with diabetes in comparison with the control, the copper content increased by $33 \%(100 \pm 6,7$ c.u.; $\mathrm{P}<0,01)$ in blood lymphocytes, $29 \%(75 \pm 4.2$ c.u.; $\mathrm{P}<0,01)-$ lymphocytes of a spleen, $19 \%(50 \pm 2,5$ c.u.; $\mathrm{P}<0,05)-$ cells of a thymus. In all cases, the established values did not differ significantly from the figures obtained in animals with streptozotocininduced diabetes.

In the case of adrenaline to rats with streptozotocininduced diabetes, the copper content was higher compared to control animals by $23 \%$ in blood lymphocytes $(92 \pm 4,2$ c.u.; $\mathrm{P}<0,01), 29 \%$ in splenic lymphocytes $(75 \pm 5,0$ c.u.; $\mathrm{P}<0,05), 19 \%$ - TEC $(50 \pm 1,7$ c.u.; $\mathrm{P}<0,05)$. For diabetic animals, the values obtained did not differ significantly.

Similar changes in the amount of metal in the cells were observed after injection of prednisolone into experimental animals. The figures obtained: $92 \pm 5,0$ c.u. ( $\mathrm{P}<0,01), 75 \pm 3,3$ c.u. $(\mathrm{P}<0,01)$ and $50 \pm 1,3$ c.u. $(\mathrm{P}<0,01)$.

The combined action of insulin and adrenaline caused in rats with streptozotocin-induced diabetes a decrease in copper content in blood lymphocytes by $23 \%(83 \pm 4,2$ c.u.; P<0,01), splenic lymphocytes - 30\% (58 $\pm 5,0$ c.u.; $\mathrm{P}<0,01)$, thymus cells $-28 \%(42 \pm 3,3$ c.u.; $\mathrm{P}<0,01)$. The difference from the control values was unreliable.

A similar nature of changes in copper content in blood lymphocytes and spleen, as well as TEC was observed after administration of insulin and prednisolone to diabetic animals. The obtained values are respectively: $83 \pm 3,3$ c.u. $(\mathrm{P}<0,01), 58 \pm 2,5$ c.u. $(\mathrm{P}<0,01), 42 \pm 5,0$ c.u. $(\mathrm{P}<0,05)$.

Thus, injections of insulin, adrenaline, and prednisolone corrected excess copper in the studied cells of the immune system of rats with streptozotocin-induced diabetes. Such changes were more pronounced in the case of the combined action of adaptive hormones.

Conclusions. 1. In rats with streptozotocin-induced diabetes, a gradual increase in copper content from cases when diabetes did not develop to severe disease: $23 \%$ $(\mathrm{P}<0,05)-56 \%(\mathrm{P}<0,001)-$ in blood lymphocytes, $16 \%$ $(\mathrm{P}<0,05)-59 \%(\mathrm{P}<0,01)-$ lymphocytes of white pulp of a spleen, $19 \%(\mathrm{P}<0,05)-79 \%(\mathrm{P}<0,001)-\mathrm{TEC}$.

2 . The content of copper in the studied cells of the immune system of control rats decreased after injection of insulin by $19 \%(\mathrm{P}<0,05)-33 \%(\mathrm{P}<0,01)$, adrenaline $40-44 \%(\mathrm{P}<0,001)$, prednisolone $-21 \%(\mathrm{P}<0,05)-33 \%$ $(\mathrm{P}<0,001)$.

3 . In rats with streptozotocin-induced diabetes, the content of intracellular copper was higher compared to the control group by $19 \%(\mathrm{P}<0,05)-33 \%(\mathrm{P}<0,01)$ after insulin administration, $19 \%(\mathrm{P}<0,05)-29 \%(\mathrm{P}<0,01)-$ adrenaline and prednisolone, but did not differ significantly from sick animals.

4. The combined action of insulin and adrenal hormones caused in diabetic rats a decrease in copper content in the TEC, blood lymphocytes and spleen by $23 \%$ $(\mathrm{P}<0,01)-28 \%(\mathrm{P}<0,01)$. 


\section{LITERATURE}

1. Боднар П. М., Михальченко Г. П, Комісаренко Ю. І Ендокринологія. Вінниця: Нова книга, 2017. 449 с.

2. Гарднер Д., Шебек Д. Базисная и клиническая эндокринология. Москва: Бином, 2019. 464 с.

3. Дедов И. И., Шестакова М. В. Сахарный диабет типа 1: реалии и перспективы: монография. Москва: Медицинское информационное агентство, 2016. 502 с.

4. Ingelfinger, J.R., Jarcho, J.A. Increase in the Incidence of Diabetes and Its Implications // N Engl J Med, 2017. 376(15). P. 1473-1474.

5. Medical Care in Diabetes - 2016 American Diabetes Association // Diabetes Care, 2016. 39, Suppl. 1. P. 2-112.

6. Ponomarenko-Jones R. Overview of diabetes // Nurse Stand, 2017. 31(3). P. 64-65.

7. Паньків В. І. Цукровий діабет: визначення, класифікація, епідеміологія, фактори ризику // Международный эндокринологический журнал, 2013. 55 (7). С. 95-104.

8. Зак К. П., Попова В. В. Предсказание развития сахарного диабета 1-го типа и диагностика его асимптомной фазы с помощью аутоантител к островкам Лангерганса поджелудочной железы у человека задолго до возникновения у него заболевания //Международный эндокринологический журнал, 2016. 79(7). С. 11-21.

9. Зак К. П., Тронько Н. Д., Попова В. В. Сахарный диабет.
Иммунитет. Цитокины: монография. Киев: Книга-плюс, $2015.485 \mathrm{c}$.

10. Zmora, N., Bashiardes, S., Levy, M. The Role of the Immune System in Metabolic Health and Disease // Cell Metab, 2017. 25(3). P. 506-521.

11. Importance of a thymus dysfunction in the pathophysiology of type 1 diabetes / V. Geenene, F. Brilot, C. Lonis [et al.] // Kev. Med. Liege, 2005. 60(5-6). P. 291-296.

12. Flynn A. Control of in vitro lymphocyte proliferation by copper, magnesium and zinc deficiency // J Nutr, 1984. 114. P. 2034-2042.

13. Tapiero, H., Townsend, D.M., Tew, K.D. Trace elements in human physiology and pathology. Copper // Biomed Pharmacother, 2003. 32(1). P. 43-54.

14. Hordyjewska, A., Popiolek, L., Kocot, J. The many "faces" of copper in medicine and treatment // Biometals, 2014. 27(4). P. 611-621.

15. Harris, E.D. Basic and clinical aspects of copper // Crit Rev Clin Lab Sci, 2003. 40(5). P. 547-586.

16. Скальный А. В. Микроэлементы: бодрость, здоровье, долголетие. Москва: Litress, 2015. 720 с.

17. Wang, X., Garrick, M.D., Collins, J.F. Animal Models of normal and disturbed iron and copper metabolism // J Nutr, 2019. 149(12). P. 2085-2100.

\section{REFERENCES}

1. Bodnar, P.M., Mikhalchenko, G.P., Komisarenko, Y.I. Endocrinology. Vinnytsia: New book, 2017. 449 p.

2. Gardner, D., Shebek, D. Basic and clinical endocrinology. Moscow: Binom, 2019. 464 p.

3. Dedov, I.I, Shestakova, M.V. Type 1 diabetes mellitus: realities and prospects: a monograph. Moscow: Medical Information Agency, 2016. 502 p.

7. Pankiv, V.I. Diabetes mellitus: definition, classification, epidemiology, risk factors // International Journal of Endocri- nology, 2013.55 (7). P. 95-104.

8. Zak, K.P., Popova, V.V. Prediction of the development of type 1 diabetes mellitus and diagnosis of its asymptomatic phase using autoantibodies to the islets of Langerhans of the pancreas in humans long before he develops the disease // International Journal of Endocrinology, 2016. 79 (7). Pp. 11-21.

9. Zak, K.P., Tronko, N.D., Popova, V.V. Diabetes mellitus. Immunity. Cytokines: a monograph. Kiev: Book-plus, 2015. $485 \mathrm{p}$. 